\title{
The Use of Inorganic Packing Materials during Methane Biofiltration
}

\author{
Josiane Nikiema and Michèle Heitz \\ Chemical Engineering Department, Faculty of Engineering, University of Sherbrooke, 2500 Boulevard de l'Université, \\ Sherbrooke, QC, Canada J1K 2R1 \\ Correspondence should be addressed to Michèle Heitz, michele.heitz@usherbrooke.ca
}

Received 18 January 2010; Accepted 26 April 2010

Academic Editor: Yves Andrès

Copyright ( $\odot 2010$ J. Nikiema and M. Heitz. This is an open access article distributed under the Creative Commons Attribution License, which permits unrestricted use, distribution, and reproduction in any medium, provided the original work is properly cited.

\begin{abstract}
The objective behind this study is to select a suitable inorganic packing material for methane biofiltration. Three packing materials are to be compared: two rock materials (average particles' sizes: 2 and $5 \mathrm{~mm}$ ) and one porous clay particles (average particle size of $7 \mathrm{~mm}$ ). The main parameter used to assess the efficiency of the packing material is the methane elimination capacity. The study reveals that the rock material having an average particle size around $2 \mathrm{~mm}$ is to be preferred. This result is probably due to its high specific surface area and to its good surface properties as compared to the other 2 tested porous materials. The influence of the nonirrigation with the nutrient solution of the biofilter is also investigated. It has been found that nonirrigation of biofilter causes the biofilter performance to decrease significantly (e.g., 45\% decrease in 1 week) even with the humidification of the gas phase prior to its introduction into the biofilter.
\end{abstract}

\section{Introduction}

Methane $\left(\mathrm{CH}_{4}\right)$ is the most important greenhouse gas (GHG) after carbon dioxide $\left(\mathrm{CO}_{2}\right)$. Its worldwide contribution to the greenhouse effect is estimated to $15 \%$ while for $\mathrm{CO}_{2}$, it is $78 \%$. Methane has a global warming potential of 21, when compared to $\mathrm{CO}_{2}$, for a lifespan in the atmosphere of around 12 years [1]. Methane emissions are encountered in agriculture, in the energy sector, and in landfills with the latter being responsible for $25 \%$ of the total $\mathrm{CH}_{4}$ emissions in Canada. It is to be noted that around $60 \%$ of the total worldwide emissions of $\mathrm{CH}_{4}$ are of anthropogenic sources $[2]$.

To avoid direct emissions into the atmosphere of the deleterious $\mathrm{CH}_{4}$, biofiltration can be used. This bioprocess involves microorganisms that biodegrade the target pollutant. The interest given to biofiltration is due to its operational cost, generally considered as lower than other elimination techniques such as the flaring. For a successful operation of a biofilter, a solid phase, also called packing material, on which the microorganisms attach and then grow, is required. Nonoptimized selection of the packing material generally yields an inefficient biological process [3] while its optimization results in lower footprint requirements.

Packing materials that may be used during $\mathrm{CH}_{4}$ biofiltration are grouped into 2 main categories: organic and inorganic materials. Organic materials include composts and soils and are generally considered by several authors as the preferred materials [4]. The main advantages of those materials are that they are easily accessible and can naturally contain methanotrophic bacteria, which exclude the necessity of an inoculation, and may result in lower start-up period (down to 1 week with compost materials and 2 weeks with soils [5]). Another advantage is that they contain nutrients, such as nitrogen and phosphorus, which are necessary for the growth of microorganisms. However, it is important to make sure that the intrinsic concentrations of the bioavailable ammonium and nitrite are minor since both compounds are known to inhibit the $\mathrm{CH}_{4}$ biodegradation [6].

Among organic materials, compost materials seem to be the most efficient, as compared to soils (this is due to the higher availability of nutrients in composts rather than 
TABLE 1: Characteristics of the tested packing materials.

\begin{tabular}{lccc}
\hline & $\begin{array}{c}\text { PM1 } \\
\text { (expanded clay-7 mm) }\end{array}$ & $\begin{array}{c}\text { PM2 } \\
\text { (rock-5 mm) }\end{array}$ & 1200 \\
(rock-2 mm)
\end{tabular}

in soils) [7]. Nevertheless, experiments conducted up till date with composts have revealed their tremendous limit during long-term experiments (the lifetime being in general $<6$ months), the suspected reasons being the compaction of the packing material, that results in an increase of the pressure drop and the apparition of channelling problems in the biofilter, and the depletion of its nutrients' content with time [8].

The inorganic packing materials have been, up till date, of minor interest during $\mathrm{CH}_{4}$ biofiltration compared to the organic materials because traditionally they are not used alone. Nevertheless, some authors use them as an additive to improve the mechanical properties of organic materials, which reduces the risks of settlement during $\mathrm{CH}_{4}$ biofiltration [9]. This group includes natural and manufactured materials such as rocks, ceramics, glass, polyurethane foam, and many others. When used during biological processes, they offer several advantages, such as a good mechanical resistance, as compared to organic materials. Furthermore, their physical properties (e.g., porosity, specific surface area, etc.) can be more easily adjusted according to the requirement of the bioprocess. However, their main disadvantage is that they generally do not contain any nutrient and, in some particular case, have high densities [10].

Very few experiments using these inorganic materials for $\mathrm{CH}_{4}$ biofiltration, especially when there is no tricking, are presented in the literature. In the first one, reported in 1993, a synthetic material composed of glass tubes $10 \mathrm{~mm}$ long and with an $8 \mathrm{~mm}$ diameter was tested for biological $\mathrm{CH}_{4}$ elimination during a biotrickling experiment. For an empty bed retention time in the biofilter of 20 minutes, a $90 \%$ $\mathrm{CH}_{4}$ conversion was reached when $\mathrm{CH}_{4}$ concentrations were approximately between 1.6 and $6.5 \mathrm{~g} / \mathrm{m}^{3}$ [11]. Also, crushed porous clay was used for $\mathrm{CH}_{4}$ removal in an open biofilter built on a real landfill site. The $\mathrm{CH}_{4}$ inlet load varied from 0 to $247 \mathrm{~g} / \mathrm{m}^{3} / \mathrm{h}$ (median value $=9.5 \mathrm{~g}-\mathrm{CH}_{4} / \mathrm{m}^{3} / \mathrm{h}$, arithmetic mean $=19 \mathrm{~g}-\mathrm{CH}_{4} / \mathrm{m}^{3} / \mathrm{h}$ ) according to the natural cycle of $\mathrm{CH}_{4}$ emissions within the landfill. Elimination capacities (ECs) of up to $80 \mathrm{~g}-\mathrm{CH}_{4} / \mathrm{m}^{3} / \mathrm{h}$ were obtained, in spite of a possible oxygen limitation occurring in the biofilter [12] Finally, Nikiema et al. [13] compared 2 filter materials: an organic (compost) and an inorganic material. Their study revealed that the inorganic material can give elimination capacities 2 times higher than those with the organic material (typically 36 versus $15 \mathrm{~g} / \mathrm{m}^{3} / \mathrm{h}$ for the inorganic and the organic materials, resp., for an IL of $75 \mathrm{~g} / \mathrm{m}^{3} / \mathrm{h}$ ).
Following the previous study, the aim of the present one is therefore to continue the investigation relative to the use of inorganic packing materials in $\mathrm{CH}_{4}$ biofilters as packing materials. Three commercial inorganic materials are selected and compared to find the one that appears to be the most efficient, when used as a packing material in a $\mathrm{CH}_{4}$ biofilter. The selection of these 3 materials is made based on their availability. Two of these materials are rocks while the third one is porous clay. Several authors have studied the influence of the gas flow rate and of the interruption of the irrigation for biofilter treating several pollutants, such as the volatile organic compounds [14]. However, to our knowledge, only the work published by Nikiema and Heitz [15] was directly related to $\mathrm{CH}_{4}$ biofiltration. To improve the knowledge of the influence of these parameters, a study has been performed and the results will be presented in the second part of this paper.

\section{Material and Methods}

The packing material 1 (PM1) is a spherical synthetic material made of expanded porous clay. It has an average particle size of around $7 \mathrm{~mm}$. The packing material 2 (PM2) is a rock material having nearly a diameter of $5 \mathrm{~mm}$. Packing material 3 (PM3) is a rock material having an average particle size of around $2 \mathrm{~mm}$. Additional properties of these 3 materials, such as their densities, water holding capacity, external specific surface area $\left(A_{s}\right)$ (i.e., excluding the surface of the microinternal pores which are generally completely covered during the biofiltration) and calculated from a method based on Jorio [16], and void fraction in the biofilter, are available in Table 1. As a pretreatment, all materials were rinsed with water to eliminate possible impurities present at their surfaces.

The flowsheet of the up-flow biofiltration system is presented in Figure 1. Each biofilter is an assembled cylindrical tube comprised of 3 identical components, each being packed with around $33 \mathrm{~cm}$ in height of packing material (total height of packing material within each biofilter: around $1 \mathrm{~m}$ ). The internal diameter of the biofilter is $0.15 \mathrm{~m}$, which led to a total reactive volume around $0.018 \mathrm{~m}^{3}$. The provided $\mathrm{CH}_{4}$ comes from a cylinder filled with almost pure methane $(99 \% \mathrm{~V} / \mathrm{V})$ purchased from Praxair Inc. (Sherbrooke, Canada). To generate the polluted gas to be introduced in a biofilter, the pure $\mathrm{CH}_{4}$ affluence is mixed with a prehumidified ambient air affluence (relative 


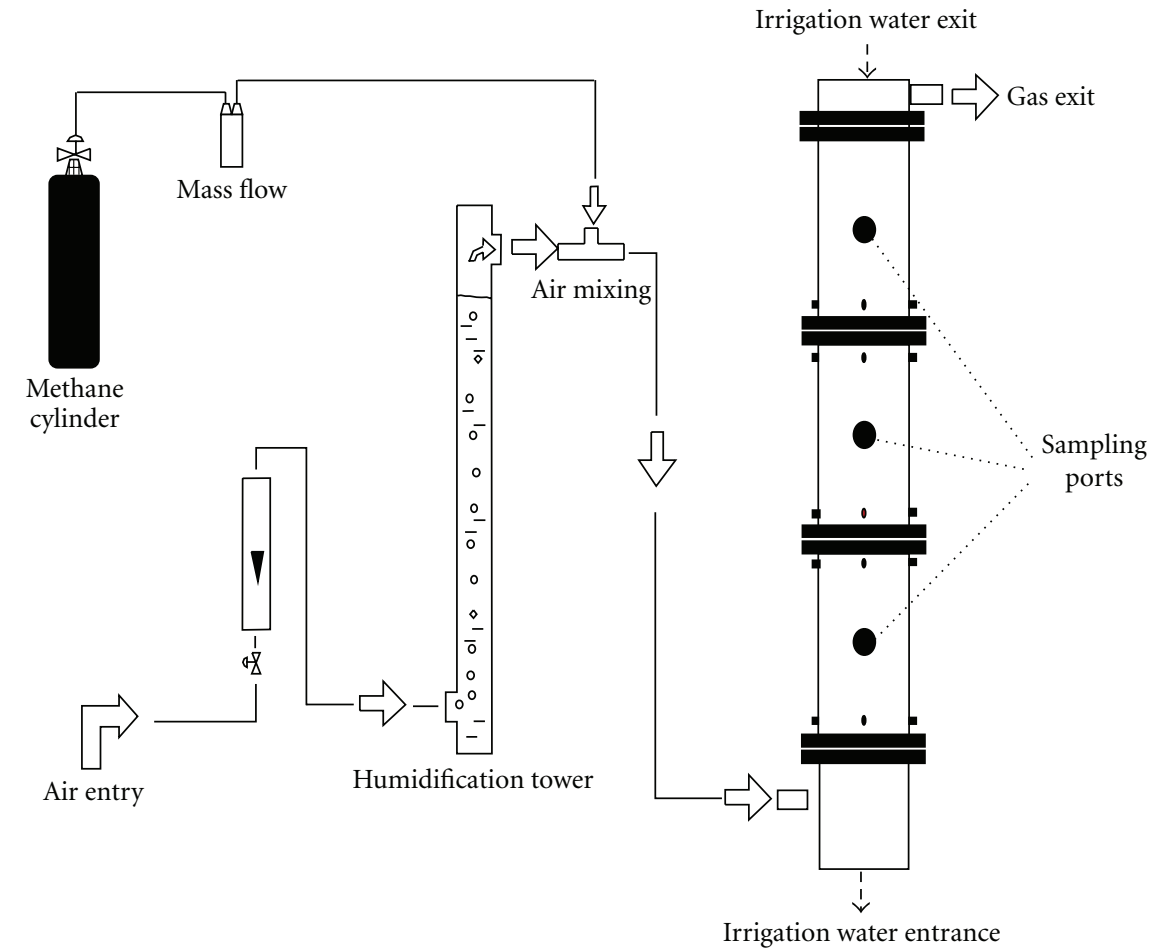

Figure 1: Lab-scale biofiltration system.

humidity $>90 \%$ ). The obtained inlet gas mixture contained approximately $0.7 \mathrm{~g} / \mathrm{m}^{3}$ of carbon dioxide (the same concentration as in the ambient air).

To maintain sufficient nutrient concentration and humidity in each biofilter, irrigation is performed once a day throughout the entire study with $0.0015 \mathrm{~m}^{3}$ of nutrient solution (excess irrigation liquid was collected at the base of the biofilter). The nutrient solution is a nitrate minimal salt solution and its composition was the following: $\mathrm{NaNO}_{3}$ : $4.55 \mathrm{~g} / \mathrm{L} ; \mathrm{Na}_{2} \mathrm{HPO}_{4}: 0.86 \mathrm{~g} / \mathrm{L} ; \mathrm{KH}_{2} \mathrm{PO}_{4}: 0.53 \mathrm{~g} / \mathrm{L} ; \mathrm{K}_{2} \mathrm{SO}_{4}$ : $0.17 \mathrm{~g} / \mathrm{L} ; \mathrm{MnSO}_{4} \cdot 7 \mathrm{H}_{2} \mathrm{O}: 0.037 \mathrm{~g} / \mathrm{L} ; \mathrm{CaCl}_{2} \cdot 2 \mathrm{H}_{2} \mathrm{O}: 0.007 \mathrm{~g} / \mathrm{L}$; $\mathrm{FeSO}_{4} \cdot 7 \mathrm{H}_{2} \mathrm{O}: 0.00112 \mathrm{~g} / \mathrm{L} ; \quad \mathrm{ZnSO}_{4} \cdot 7 \mathrm{H}_{2} \mathrm{O}: 0.000576 \mathrm{~g} / \mathrm{L}$; $\mathrm{MnSO}_{4} \cdot 7 \mathrm{H}_{2} \mathrm{O}: 0.000466 \mathrm{~g} / \mathrm{L} ; \mathrm{CuSO}_{4} \cdot 5 \mathrm{H}_{2} \mathrm{O}: 0.00025 \mathrm{~g} / \mathrm{L}$; KI: $0.000166 \mathrm{~g} / \mathrm{L} ; \mathrm{H}_{3} \mathrm{BO}_{3}: 0.000124 \mathrm{~g} / \mathrm{L} ; \mathrm{NaMoO}_{4} \cdot 2 \mathrm{H}_{2} \mathrm{O}$ : $0.000096 \mathrm{~g} / \mathrm{L} ; \mathrm{CoCl}_{2} \cdot 6 \mathrm{H}_{2} \mathrm{O}: 0.000096 \mathrm{~g} / \mathrm{L}$ for $1 \mathrm{~L}$ of water solution.

The parameters used for the description of the results defined in Table 2 are inlet load (IL), conversion (X), elimination capacity (EC), specific elimination capacity $\left(\mathrm{EC}_{\mathrm{sp}}\right)$, and $\mathrm{CO}_{2}$ production rate $\left(\mathrm{P}_{\mathrm{CO}_{2}}\right)$. The follow-up of the biofilter performance, that is, concentrations of $\mathrm{CH}_{4}$ and $\mathrm{CO}_{2}$ at the entry and exit of each stage, is achieved using two analyzers, one of total hydrocarbons from Horiba (Model FIA 510) and the other of $\mathrm{CO}_{2}$ from Siemens (Model Ultramat 22P). The pressure drop is monitored through a differential manometer (Air Flow Development Ltd., UK, type 4). A T-type thermocouple, connected to a read-out unit (Omega, model DP465), was also used, to monitor the temperature.

\section{Results and Discussion}

3.1. Influence of the Packing Material. Figure 2(a) represents the EC $\left(\mathrm{g} / \mathrm{m}^{3} / \mathrm{h}\right)$, measured when steady state was reached in the biofilters packed with PM1, PM2, and PM3, as a function of the IL. It is to be recalled that steady state corresponds to a week period during which the variation of the EC with time, for a constant IL, is $<5 \%$. To perform the experiment, the flow rate of the polluted air introduced at the base of the biofilter is maintained at $4.2 \mathrm{~L} / \mathrm{min}$ (i.e., an empty bed residence time of around $4.1 \mathrm{~min}$ ) and the $\mathrm{CH}_{4}$ concentration used is between 0.5 and $6.3 \mathrm{~g} / \mathrm{m}^{3}$ (higher $\mathrm{CH}_{4}$ concentrations could not be tested for safety reasons).

In Figure 2(a), a continuous increase of the EC with the IL is observed in all 3 packing materials. Further, the present study range highlights 2 main operation domains: firstly, a continuous linear increase of the EC with the IL when it is between 0 and $50 \mathrm{~g} / \mathrm{m}^{3} / \mathrm{h}$, and then, secondly, a deceleration favouring lower levels of increase in the EC with the IL when it is superior to $50 \mathrm{~g} / \mathrm{m}^{3} / \mathrm{h}$, which is confirmed by the decrease of the slope of the curve presenting the EC as a function of the IL. For example, with PM3, the slope is initially 0.70 when IL $\leq 50 \mathrm{~g} / \mathrm{m}^{3} / \mathrm{h}$ (i.e., diffusion limitation) and decreases to 0.35 when IL $\geq 50 \mathrm{~g} / \mathrm{m}^{3} / \mathrm{h}$. This deceleration is probably a consequence of the saturation in the biomass performance (i.e., reaction limitation). The maximum $\mathrm{CH}_{4} \mathrm{EC}$ values for this experiment, measured at a $\mathrm{CH}_{4}$ IL of around $90 \mathrm{~g} / \mathrm{m}^{3} / \mathrm{h}$, are 17,38 , and $50 \mathrm{~g} / \mathrm{m}^{3} / \mathrm{h}$ within PM1, PM2, and PM3, respectively. This leads to the conclusion that PM3 is more 
TABLE 2: Determination of the quantitative parameters.

\begin{tabular}{|c|c|}
\hline Parameters & Methods of determination \\
\hline IL: Volumetric inlet load $\left(\mathrm{g} / \mathrm{m}^{3} / \mathrm{h}\right)$ & $\mathrm{IL}=\frac{C_{\left(\mathrm{CH}_{4}\right) \text { in }} \times Q}{V}$ \\
\hline $\mathrm{X}$ : Conversion $(\%)$ & $\mathrm{X}=\frac{C_{\left(\mathrm{CH}_{4}\right) \text { in }}-C_{\left(\mathrm{CH}_{4}\right) \text { out }}}{C_{\left(\mathrm{CH}_{4}\right) \text { in }}} \times 100$ \\
\hline EC: Elimination capacity $\left(\mathrm{g} / \mathrm{m}^{3} / \mathrm{h}\right)$ & $\mathrm{EC}=\mathrm{IL} \times \mathrm{X}$ \\
\hline $\mathrm{EC}_{\mathrm{sp}}:$ Specific EC $\left(\mathrm{g} / \mathrm{m}^{2} / \mathrm{h}\right)$ & $\mathrm{EC}_{\mathrm{sp}}=\frac{\mathrm{EC}}{A_{s}}$ \\
\hline$P_{\mathrm{CO}_{2}}$ : Carbon dioxide production rate $\left(\mathrm{g} / \mathrm{m}^{3} / \mathrm{h}\right)$ & $P_{\mathrm{CO}_{2}}=\frac{\left(C_{\left(\mathrm{CO}_{2}\right)_{\text {out }}}-C_{\left(\mathrm{CO}_{2}\right)_{\text {in }}}\right) \times Q}{V}$ \\
\hline
\end{tabular}

$C_{\mathrm{CH}_{4}}$ : Methane concentration in $\mathrm{g} / \mathrm{m}^{3} ; C_{\mathrm{CO}_{2}}$ : Carbon dioxide concentration in $\mathrm{g} / \mathrm{m}^{3} ; Q=$ Volumetric flow rate of air mixture in $\mathrm{m}^{3} / \mathrm{h} ; \mathrm{V}:$ Biofilter volume in $\mathrm{m}^{3} ; A_{s}$ : external specific surface area in $\mathrm{m}^{2}$ of packing surface per $\mathrm{m}^{3}$ of biofilter.

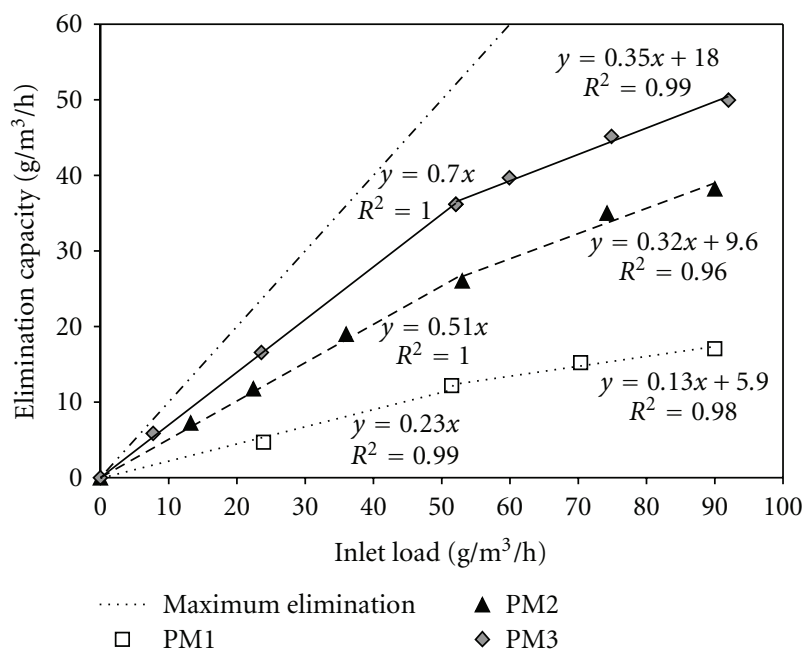

(a)

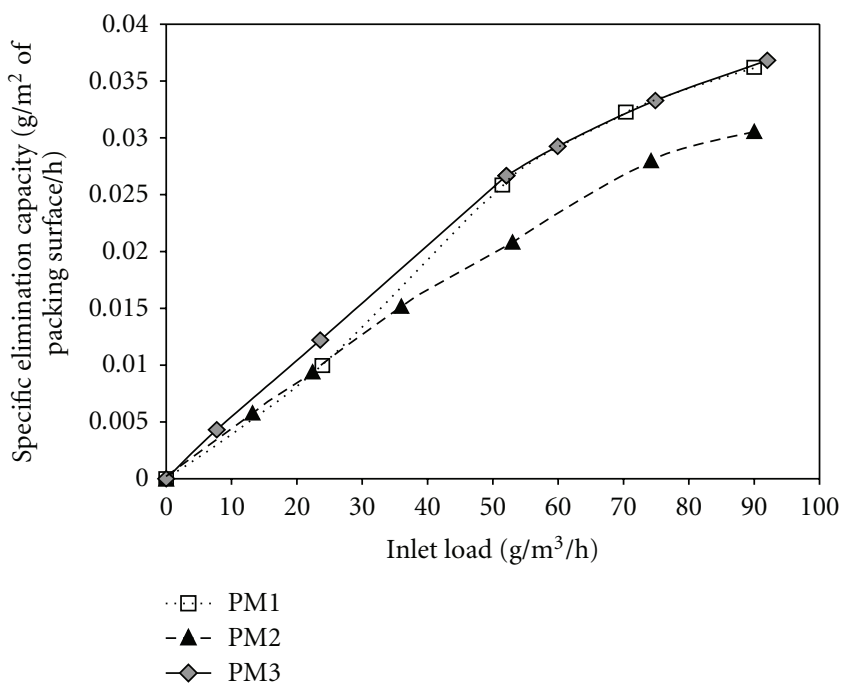

(b)

Figure 2: (a) $\mathrm{EC}$ of $\mathrm{CH}_{4}$ as a function of the $\mathrm{CH}_{4} \mathrm{IL}$ for the 3 tested packing materials. (b) $\mathrm{EC}_{\mathrm{sp}}$ of $\mathrm{CH}_{4}$ as a function of the $\mathrm{CH}_{4} \mathrm{IL}$ for the 3 tested packing materials.

efficient than the 2 others, at similar conditions, and seems to be an appropriate packing material for $\mathrm{CH}_{4}$ biofiltration.

To explain this result, one can think of the fact that the $A_{s}$ values are different for the 3 packing materials $\left(A_{s}\right.$ depends mainly on the particle size of the packing material and on its void fraction in the biofilter). For the present study, $A_{s}$ (PM3) is around 10\% higher than $A_{s}$ (PM2) and 190\% higher than $A_{s}$ (PM1). It is also commonly accepted that high $A_{s}$ values are favourable for pollutants' removal by biofiltration because the biofilm surface is increased, which causes an increase of the total amount of pollutant that is transferred from the gas phase to the biofilm. On the other hand, the effect of $A_{s}$ value on the biofilter efficiency is more and more obvious, as the IL is increased [9]. Typically, at the IL of around $90 \mathrm{~g}-\mathrm{CH}_{4} / \mathrm{m}^{3} / \mathrm{h}$ (the highest IL tested for this study), EC (PM3) is 190\% and 30\% higher than EC (PM1) and EC (PM2) (Figure 2(a)). This means that, at this IL, the $190 \%$ higher $A_{s}$ value of PM3 can explain its superiority, in terms of measured EC, as compared to PM1. However, for PM2 and PM3 (differences of $10 \%$ and $30 \%$ for the $A_{s}$ values and the EC, resp.), there is at least one additional factor (other than $A_{s}$ ) that also affects the packing material efficiency and accounted for $20 \%$ of the difference in the values of EC. This (or these) additional factor(s) can be related to the surface properties of packing materials.

Indeed, according to several authors, the fixation of microorganisms on a solid packing material depends on several parameters (combined herein through the appellation: surface properties), which can include the extracellular polysaccharide (EPS) production of the microorganisms, the roughness of the packing material surface, and also the charge and the hydrophobicity of both the microorganisms' cells and packing material surfaces [17-20]. Therefore, some packing materials' surfaces can appear to be more or less suitable for some methanotrophs, which would result, in the $\mathrm{CH}_{4}$ biofilter, in high or low densities of biomass per unit of packing surface. Because high $\mathrm{CH}_{4}$ removal efficiencies are usually associated with high biomass density (except when 


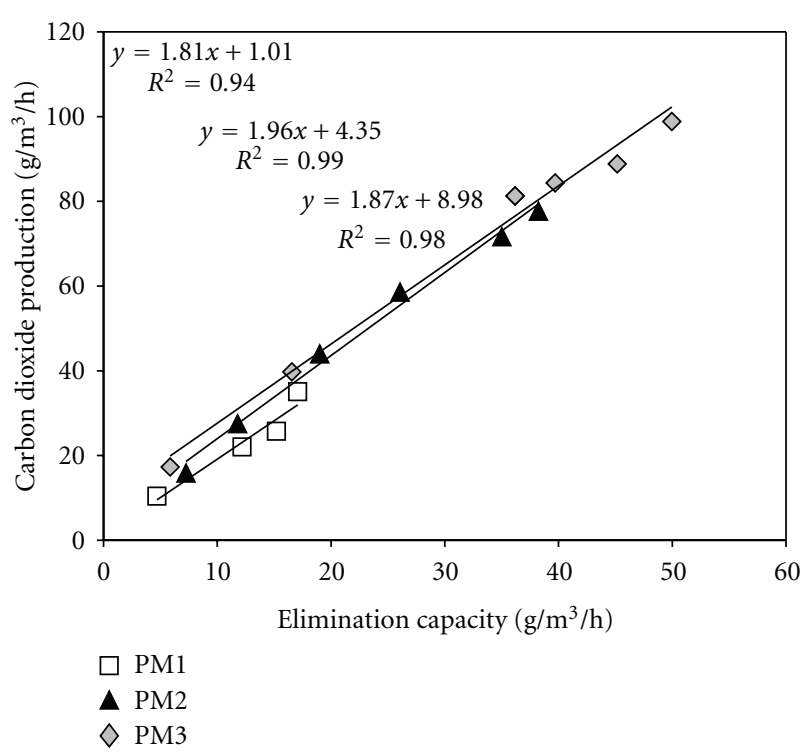

Figure 3: $\mathrm{CO}_{2}$ production as a function of the $\mathrm{EC}$ of $\mathrm{CH}_{4}$ in the biofilters packed with PM1, PM2, or PM3.

clogging occurs, which was not observed in our study), the surface properties of the packing material affect the overall $\mathrm{CH}_{4}$ elimination process efficiency.

To determine the relative contribution of these surface properties of PM3 to its performance, the graph in Figure 2(b) has been constructed. It represents the specific elimination capacity $\left(\mathrm{EC}_{\mathrm{sp}}\right)$, expressed in $\mathrm{g} \mathrm{CH}_{4}$ eliminated per $\mathrm{m}^{2}$ of packing material surface and per hour, as a function of the methane inlet load $\left(\mathrm{g} / \mathrm{m}^{3} / \mathrm{h}\right)$ for the 3 tested packing materials. The $A_{s}$ remained almost constant because of the low biomass growth rates in the $\mathrm{CH}_{4}$ biofilter [21]. $\mathrm{EC}_{\mathrm{sp}}$ represents the actual efficiency in $\mathrm{CH}_{4}$ removal associated with a given external surface of packing materials. Since $\mathrm{EC}_{\text {sp }}$ does not depend on $A_{s}$, it therefore allows the comparison of the performance of the 3 packing materials in terms of their surface properties only. Consequently, high $\mathrm{EC}_{\mathrm{sp}}$ values are associated with good surface properties (favouring the attachment of active methanotrophs and the development of a biofilm).

From Figure 2(b), it appears that, for inlet load $<25 \mathrm{~g} / \mathrm{m}^{3} / \mathrm{h}$ (i.e., $\mathrm{CH}_{4}$ concentrations $<1.6 \mathrm{~g} / \mathrm{m}^{3}$ ), the 3 packing materials are almost equivalent in terms of $\mathrm{CH}_{4}$ removal per packing surface unit but, as the $\mathrm{CH}_{4}$ IL increases, PM1 and PM3 reveals to be slightly better than PM2, with $\mathrm{EC}_{\mathrm{sp}}$ reaching values $20 \%$ higher than within PM2. For example, at an IL of $90 \mathrm{~g} / \mathrm{m}^{3} / \mathrm{h}$, one obtains $\mathrm{EC}_{\text {sp }}$ of 0.036 and $0.037 \mathrm{~g} / \mathrm{m}^{2} / \mathrm{h}$, for PM1 and PM3, respectively, while for $\mathrm{PM} 2, \mathrm{EC}_{\mathrm{sp}}$ is $0.031 \mathrm{~g} / \mathrm{m}^{2} / \mathrm{h}$.

As an overall conclusion, if the EC of PM3 is superior to the EC of PM1, it should be mainly because of its high $A_{s}$ value. This means that if the $A_{s}$ of PM1 was increased (e.g., after reducing the particle size), it could theoretically perform as well as PM3. On the other hand, if PM3 is superior to PM2, it is because of both its high $A_{s}$ value (which contributed, in these experiments, to $1 / 3$ of the difference in

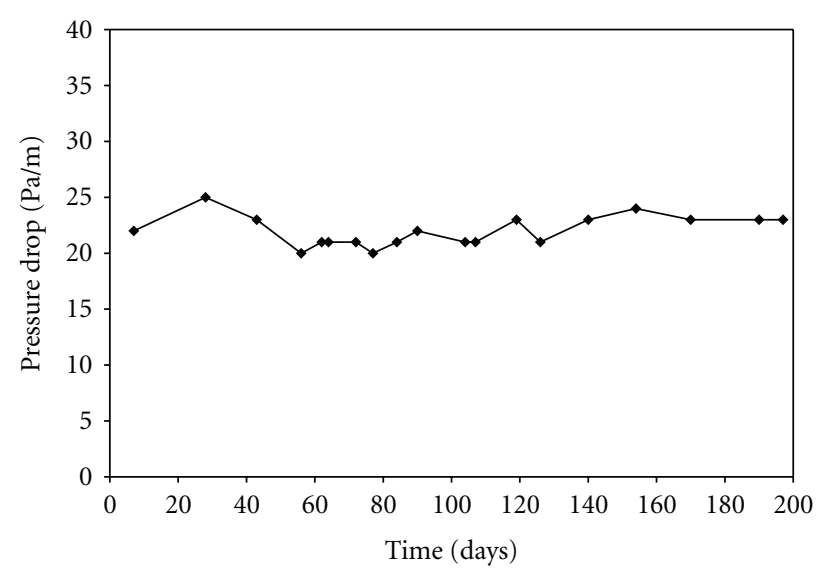

Figure 4: Pressure drop as a function of time in the PM3 biofilter.

EC values measured between PM3 and PM2) and its better surface properties (i.e., 2/3 of the difference in ECs observed between PM3 and PM2). Therefore, even after increasing the $A_{s}$ of PM2, it should, in theory, remain less efficient than PM3 because it does not have good surface properties.

Throughout this study, the total $\mathrm{CO}_{2}$ production within the biofilter is monitored. In all 3 packing materials, it can be noted that both the EC and the $P_{\mathrm{CO}_{2}}$ follow the same tendency. As a consequence, all trends of the $P_{\mathrm{CO}_{2}}$ $\left(\mathrm{g} / \mathrm{m}^{3} / \mathrm{h}\right)$ displayed as a function of the EC $\left(\mathrm{g}-\mathrm{CH}_{4} / \mathrm{m}^{3} / \mathrm{h}\right)$ in the biofilter packed with PM1, PM2, or PM3 are linear (Figure 3). From Figure 3, it appears that $1.8 \mathrm{~g}$ to $2 \mathrm{~g}$ of $\mathrm{CO}_{2}$ are produced per $\mathrm{g}$ of $\mathrm{CH}_{4}$ eliminated by each $\mathrm{CH}_{4}$ biofilter. This also means that no more than $65 \%-72 \%$ of the carbon in $\mathrm{CH}_{4}$ is converted into $\mathrm{CO}_{2}$ by the microorganisms during the biodegradation (Table 3) - the remaining part is generally used for synthesis of EPS and new biomass [22]. The biofiltration of $\mathrm{CH}_{4}$ reveals therefore to be very appealing, as compared to other chemical oxidation processes since it reduces the emissions of greenhouse gas $\mathrm{CO}_{2}$. The percentages of $\mathrm{CH}_{4}$ converted into $\mathrm{CO}_{2}$ in this study are in the same order of magnitude than those presented in the literature, which are $70 \%$ during $\mathrm{CH}_{4}$ biotrickling and $60 \%$ during biofiltration of $\mathrm{CH}_{4}$ in atmospheric air $[11,23]$. The fact that the $\mathrm{CO}_{2}$ productions are almost similar in all 3 biofilters could suggest that their biomasses were behaving similarly (e.g., similar bacterial growth rate), but microbial analysis has not been performed to confirm this hypothesis.

Figure 4 displays the pressure drop as a function of time in the PM3 biofilter. Because of the particle bed size of PM3 (around $2 \mathrm{~mm}$ ), as compared to the one of PM1 and PM2 ( $7 \mathrm{~mm}$ and $5 \mathrm{~mm}$, resp.), a pressure drop between $20 \mathrm{~Pa} / \mathrm{m}$ and $25 \mathrm{~Pa} / \mathrm{m}$, higher than the ones measured in biofilters packed with PM1 $(<1 \mathrm{~Pa} / \mathrm{m})$ and PM2 $(<2 \mathrm{~Pa} / \mathrm{m})$, is measured in the biofilter packed with PM3. However, there was no increase with time, over more than 6 months, of the pressure drop in all 3 biofilters. Indeed, variation of the pressure drop is usually the result of the excessive biomass growth in the biofilter, which happens not to be the case in this experiment at the tested operating conditions. 
TABLE 3: Main results for the 3 tested packing materials.

\begin{tabular}{|c|c|c|c|}
\hline & $\begin{array}{c}\text { PM1 } \\
\text { (expanded clay-7 mm) }\end{array}$ & $\begin{array}{c}\text { PM2 } \\
(\text { rock- } 5 \mathrm{~mm})\end{array}$ & $\begin{array}{c}\text { PM3 } \\
\text { (rock-2 mm) }\end{array}$ \\
\hline Maximum EC $\left(\mathrm{g} / \mathrm{m}^{3} / \mathrm{h}\right)$ & 17 & 38 & 50 \\
\hline EC and $P_{\mathrm{CO}_{2}}$ : Similar tendencies & Yes & Yes & Yes \\
\hline Average percentage of $\mathrm{CH}_{4}$ converted into $\mathrm{CO}_{2}$ & 65.8 & 71.2 & 68.0 \\
\hline Maximum bed temperature $\left({ }^{\circ} \mathrm{C}\right)$ & 27.2 & 29.1 & 30.6 \\
\hline Pressure drop $(\mathrm{Pa})$ & $<1$ & $<2$ & $20-25$ \\
\hline
\end{tabular}

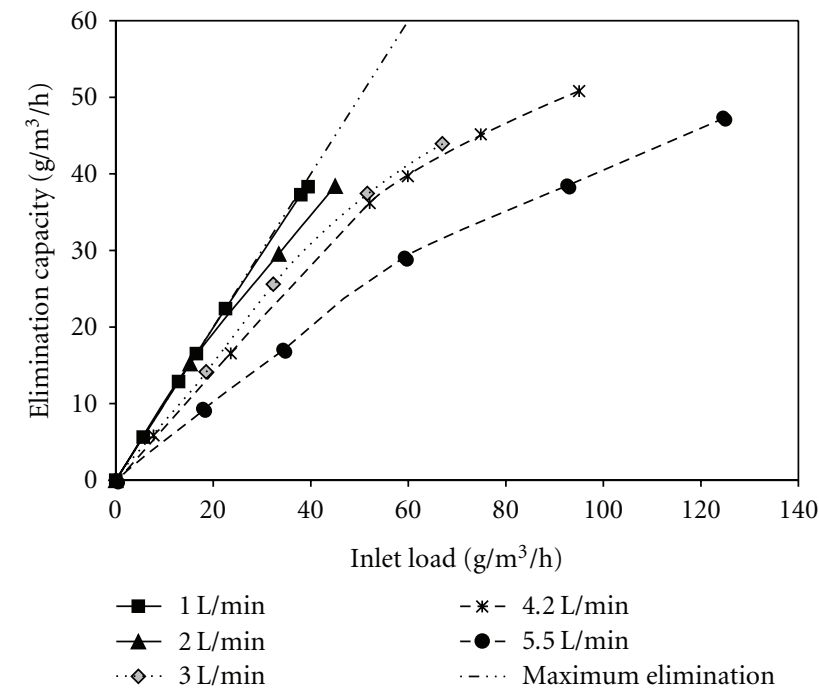

(a)

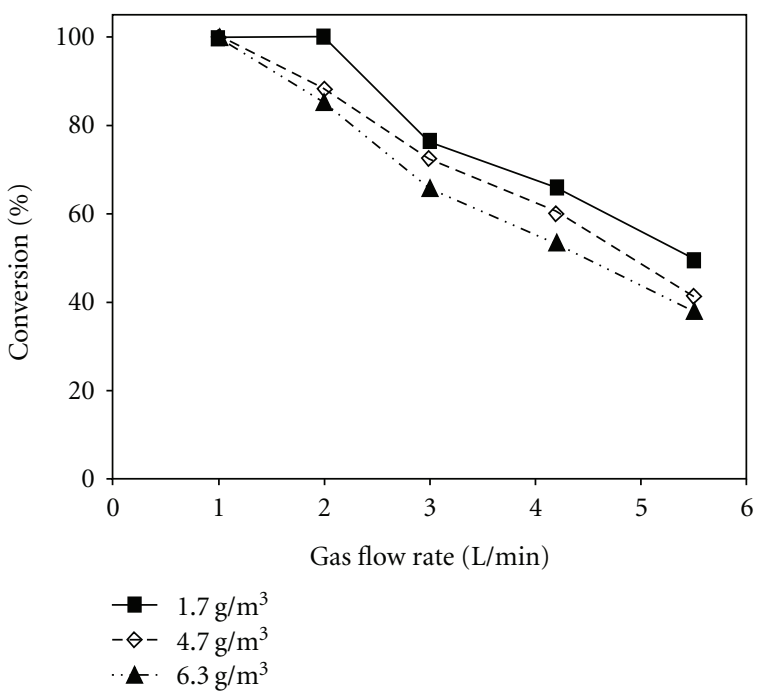

(b)

FIGURE 5: (a) EC of $\mathrm{CH}_{4}$ within the biofilter packed with PM3 as a function of the IL for GFR comprised between 1 and $5.5 \mathrm{~L} / \mathrm{min}$. (b) $\mathrm{CH} 4$ conversion as a function of the GFR for $\mathrm{CH}_{4}$ concentrations of $1.7,4.7$, and $6.3 \mathrm{~g} / \mathrm{m}^{3}$.

Moreover, within the PM3-packed bed biofilter, the highest average temperature $\left(30.6^{\circ} \mathrm{C}\right)$ is obtained for an IL of around $90 \mathrm{~g} / \mathrm{m}^{3} / \mathrm{h}$ and was between $1.5^{\circ} \mathrm{C}$ and $3.4^{\circ} \mathrm{C}$ higher than those in PM2 and PM1, respectively, under similar operating conditions (Table 3).

3.2. Influence of the Flow Rate on Packing Material 3. To determine the impact of gas flow rate variation on the efficiency of PM3, experiments have been conducted. Figure 5(a) shows the EC within the biofilter packed with PM3 as a function of the IL when the gas flow rate is maintained at between $1 \mathrm{~L} / \mathrm{min}$ and $5.5 \mathrm{~L} / \mathrm{min}$. The $\mathrm{CH}_{4}$ concentration is generally varied between 0.9 and $6.3 \mathrm{~g} / \mathrm{m}^{3}$, except at $1 \mathrm{~L} / \mathrm{min}$, for which higher $\mathrm{CH}_{4}$ concentrations, that is, reaching $11 \mathrm{~g} / \mathrm{m}^{3}$, are also investigated. It is noted that gas flow rates of $\leq 2 \mathrm{~L} / \mathrm{min}$ are preferable in order to obtain the highest EC. For a similar $\mathrm{CH}_{4}$ concentration, the increase of the inlet gas flow rate causes an increase in the IL values and also of the EC. On the other hand, for a similar IL, the higher the GFR is, the lower is the biofilter EC. At a gas flow of $1 \mathrm{~L} / \mathrm{min}$, the critical load is $\geq 40 \mathrm{~g} / \mathrm{m}^{3} / \mathrm{h}$. It is to be noted that a similar study has been conducted previously using another inorganic packing material [15] and the same GFR operation range $(\leq 2 \mathrm{~L} / \mathrm{min})$ was identified.
Figure 5(b) depicts, on the other hand, the $\mathrm{CH}_{4}$ conversion as a function of the GFR for 3 methane concentrations, that is, $1.7,4.7$, and $6.3 \mathrm{~g} / \mathrm{m}^{3}$. It is confirmed from Figure $5(\mathrm{~b})$ that the increase of the GFR from 1 to $5.5 \mathrm{~L} / \mathrm{min}$ causes the conversion to decrease from $100 \%$ to $38 \%$, which corresponds to a $14 \%$ decrease in the conversion after a $1 \mathrm{~L} / \mathrm{min}$ increase in the GFR. For the lower methane concentration level (i.e., $1.7 \mathrm{~g} / \mathrm{m}^{3}$ ), the decrease in the conversion following the increase in the GFR begins at a GFR above $2 \mathrm{~L} / \mathrm{min}$, while for the other $\mathrm{CH}_{4}$ concentrations levels, it starts at $1 \mathrm{~L} / \mathrm{min}$. This is the consequence of the fact that inhibition occurs more easily at high $\mathrm{CH}_{4}$ concentrations than at lower $\mathrm{CH}_{4}$ concentrations.

3.3. Influence of Interrupting Biofilter Irrigation. Figure 6 illustrates the conversion as a function of time at a GFR of $5.5 \mathrm{~L} / \mathrm{min}$ and a $\mathrm{CH}_{4}$ concentration of $2.3 \mathrm{~g} / \mathrm{m}^{3}$. This study aims at measuring the robustness of the biofilter packed with the PM3 packing material. At day 0 , the biofilter is irrigated (after measurement of the biofilter performance) and is kept in operation without additional nutrient solution until day 18. It is to be noted that the gas introduced in the biofilter was continuously humidified at a level of around $90 \%$ of relative humidity. The nonirrigation of the biofilter causes the biofilter performance to decrease with time. For 


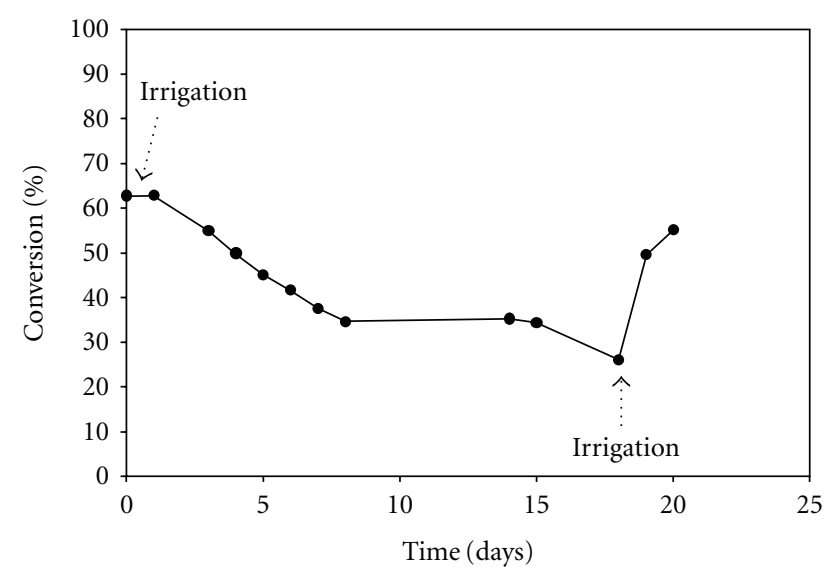

Figure 6: Conversion of $\mathrm{CH}_{4}$ as a function of time at a GFR of $5.5 \mathrm{~L} / \mathrm{min}$ and $\mathrm{a} \mathrm{CH}_{4}$ inlet concentration of $2.3 \mathrm{~g} / \mathrm{m}^{3}$.

example, it takes 7 days for the conversion to decrease from $63 \%$ to $35 \%$. After that period, the conversion of the biofilter remains almost constant for an additional week (from day 8 until day 15). In overall, after 17 days of nonirrigation, the $\mathrm{CH}_{4}$ conversion within the biofilter falls to 26\% (a 60\% decrease in the conversion). This decrease can be mainly attributed to the depletion of nutrients available for $\mathrm{CH}_{4}$ elimination within the $\mathrm{CH}_{4}$ biofilter. Once the irrigation is started again at day 18, a rapid recovery of the biofilter performance is noted. From day 18 to day 19, the conversion within the biofilter doubles to $50 \%$. The day after, the conversion is only $13 \%$ lower than the normal value, that is, the one measured at days 0 and 1 (then the conversion continues to increase until reaching the value of day 0 ). This confirms that irrigation with a nutrient solution, in the case of inorganic packing materials, is a very important parameter for the effective elimination of $\mathrm{CH}_{4}$.

\section{Conclusion}

The main objective of this study was to compare 3 inorganic packing materials to identify the most efficient for $\mathrm{CH}_{4}$ biofiltration. Of these materials, PM3, the rock material having an average particle size of $2 \mathrm{~mm}$ appeared to be the most efficient compared to the 2 others (PM1: porous clay $(\sim 7 \mathrm{~mm})$ and PM2: rock $(\sim 5 \mathrm{~mm}))$. The reasons of its superiority are linked to the fact that it has the highest surface area and good "surface properties". The highest $\mathrm{CH}_{4}$ EC was around $50 \mathrm{~g} / \mathrm{m}^{3} / \mathrm{h}$ for an IL of $90 \mathrm{~g}-\mathrm{CH}_{4} / \mathrm{m}^{3} / \mathrm{h}$. With PM3, the gas flow rate must be kept under or at $2 \mathrm{~L} / \mathrm{min}$ for best performance. In such conditions, it was noted that the biofilter conversion was at least of $80 \%$ for $\mathrm{CH}_{4}$ concentrations of up to $6.3 \mathrm{~g} / \mathrm{m}^{3}$. Also, this study revealed that irrigation of PM3 with a suitable nutrient solution is determinant for biofilter efficiency. Indeed, after 1 week without nutrient solution provision, it was noted that the $\mathrm{CH}_{4}$ conversion within the biofilter was reduced by half. With all packing materials, the carbon dioxide production followed a tendency that was similar to the one of the EC. In addition, between $1.8 \mathrm{~g}$ and $2 \mathrm{~g}$ of $\mathrm{CO}_{2}$ were generated in each biofilter per $\mathrm{g}$ of eliminated $\mathrm{CH}_{4}$.

\section{Acknowledgments}

The authors are indebted to the Natural Science and Engineering Research Council of Canada (NSERC) for their financial support to this project. In particular, the coauthor, J. Nikiema, would also like to thank NSERC for providing the supporting scholarship for her doctoral studies (Canada Graduate Scholarships Program). The authors are also indebted to Balkrishna Sharma Gukhool for text revision.

\section{References}

[1] J. Nikiema, R. Brzezinski, and M. Heitz, "Elimination of methane generated from landfills by biofiltration: a review," Reviews in Environmental Science and Biotechnology, vol. 6, no. 4, pp. 261-284, 2007.

[2] C. Pellerin, Tirer le meilleur parti possible du méthane, The Student Operated Press, Vero Beach, Fla, USA, 2007, consulted in 2010, http://thesop.org/index.php?article $=7175$.

[3] Z. Shareefdeen, B. Herner, D. Webb, S. Polenek, and S. Wilson, "Removing volatile organic compound (VOC) emissions from a printed circuit board manufacturing facility using pilot- and commercial-scale biofilters," Environmental Progress, vol. 21, no. 3, pp. 196-201, 2002.

[4] H.-P. Horz, V. Rich, S. Avrahami, and B. J. M. Bohannan, "Methane-oxidizing bacteria in a California upland grassland soil: diversity and response to simulated global change," Applied and Environmental Microbiology, vol. 71, no. 5, pp. 2642-2652, 2005.

[5] J. H. Wilshusen, J. P. A. Hettiaratchi, A. de Visscher, and R. Saint-Fort, "Methane oxidation and formation of EPS in compost: effect of oxygen concentration," Environmental Pollution, vol. 129, no. 2, pp. 305-314, 2004.

[6] M. Humer and P. Lechner, "Microbial methane oxidation for the reduction of landfill gas emissions," Journal of Solid Waste Technology and Management, vol. 27, no. 3-4, pp. 146-151, 2001.

[7] S. Y. Park, K. W. Brown, and J. C. Thomas, "The use of biofilters to reduce atmospheric methane emissions from landfills: part I. Biofilter design," Water, Air, and Soil Pollution, vol. 155, no. 1-4, pp. 63-85, 2004.

[8] J. Streese, B. Dammann, and R. Stegmann, "Reduction of methane and trace gas emissions from former landfills in biofilters," in Proceedings of the 8th International Waste Management and Landfill Symposium, S. Margherita di Pula, Ed., pp. 575-584, SWANA-Solid Waste Association of North America, Cagliari, Italy, October 2001.

[9] K. A. Janni, W. J. Maier, T. H. Kuehn et al., "Evaluation of biofiltration of air-an innovative air pollution control technology," ASHRAE Transactions, vol. 107, part 1, pp. 198214, 2001.

[10] J. W. van Groenestijn and N. J. R. Kraakman, "Recent developments in biological waste gas purification in Europe," Chemical Engineering Journal, vol. 113, no. 2-3, pp. 85-91, 2005.

[11] L. I. Sly, L. J. Bryant, J. M. Cox, and J. M. Anderson, "Development of a biofilter for the removal of methane from coal mine ventilation atmospheres," Applied Microbiology and Biotechnology, vol. 39, no. 3, pp. 400-404, 1993.

[12] J. Gebert and A. Groengroeft, "Passive landfill gas emissioninfluence of atmospheric pressure and implications for the operation of methane-oxidising biofilters," Waste Management, vol. 26, no. 3, pp. 245-251, 2006. 
[13] J. Nikiema, L. Bibeau, J. Lavoie, R. Brzezinski, J. Vigneux, and M. Heitz, "Biofiltration of methane: an experimental study," Chemical Engineering Journal, vol. 113, no. 2-3, pp. 111-117, 2005.

[14] C. Kennes and M. C. Veiga, Bioreactors for Waste Gas Treatment, Kluwer Academic Publishers, Dordrecht, The Netherlands, 2001.

[15] J. Nikiema and M. Heitz, "The influence of the gas flow rate during methane biofiltration on an inorganic packing material," Canadian Journal of Chemical Engineering, vol. 87, no. 1, pp. 136-142, 2009.

[16] H. Jorio, Biofiltration de l'air contaminé par des composés organiques volatils, Ph.D. dissertation, Department of Chemical Engineering, Faculty of Engineering, Universite de Sherbrooke, Sherbrooke, Canada, 2000.

[17] M. Pasmore, P. Todd, B. Pfiefer, M. Rhodes, and C. N. Bowman, "Effect of polymer surface properties on the reversibility of attachment of Pseudomonas aeruginosa in the early stages of biofilm development," Biofouling, vol. 18, no. 1, pp. 65-71, 2002.

[18] D. Seghers, S. D. Siciliano, E. M. Top, and W. Verstraete, "Combined effect of fertilizer and herbicide applications on the abundance, community structure and performance of the soil methanotrophic community," Soil Biology and Biochemistry, vol. 37, no. 2, pp. 187-193, 2005.

[19] D. Dimitrov, D. Hadjiev, and I. Nikov, "Optimisation of support medium for particle-based biofilm reactors," Biochemical Engineering Journal, vol. 37, no. 3, pp. 238-245, 2007.

[20] A. Jain, K. K. Nishad, and N. B. Bhosle, "Effects of DNP on the cell surface properties of marine bacteria and its implication for adhesion to surfaces," Biofouling, vol. 23, no. 3, pp. 171177, 2007.

[21] M.-C. Delhoménie, J. Nikiema, L. Bibeau, and M. Heitz, "A new method to determine the microbial kinetic parameters in biological air filters," Chemical Engineering Science, vol. 63, no. 16, pp. 4126-4134, 2008.

[22] H. A. Hilger, D. F. Cranford, and M. A. Barlaz, "Methane oxidation and microbial exopolymer production in landfill cover soil," Soil Biology and Biochemistry, vol. 32, no. 4, pp. 457-467, 2000.

[23] J. Le Mer and P. Roger, "Production, oxidation, emission and consumption of methane by soils: a review," European Journal of Soil Biology, vol. 37, no. 1, pp. 25-50, 2001. 

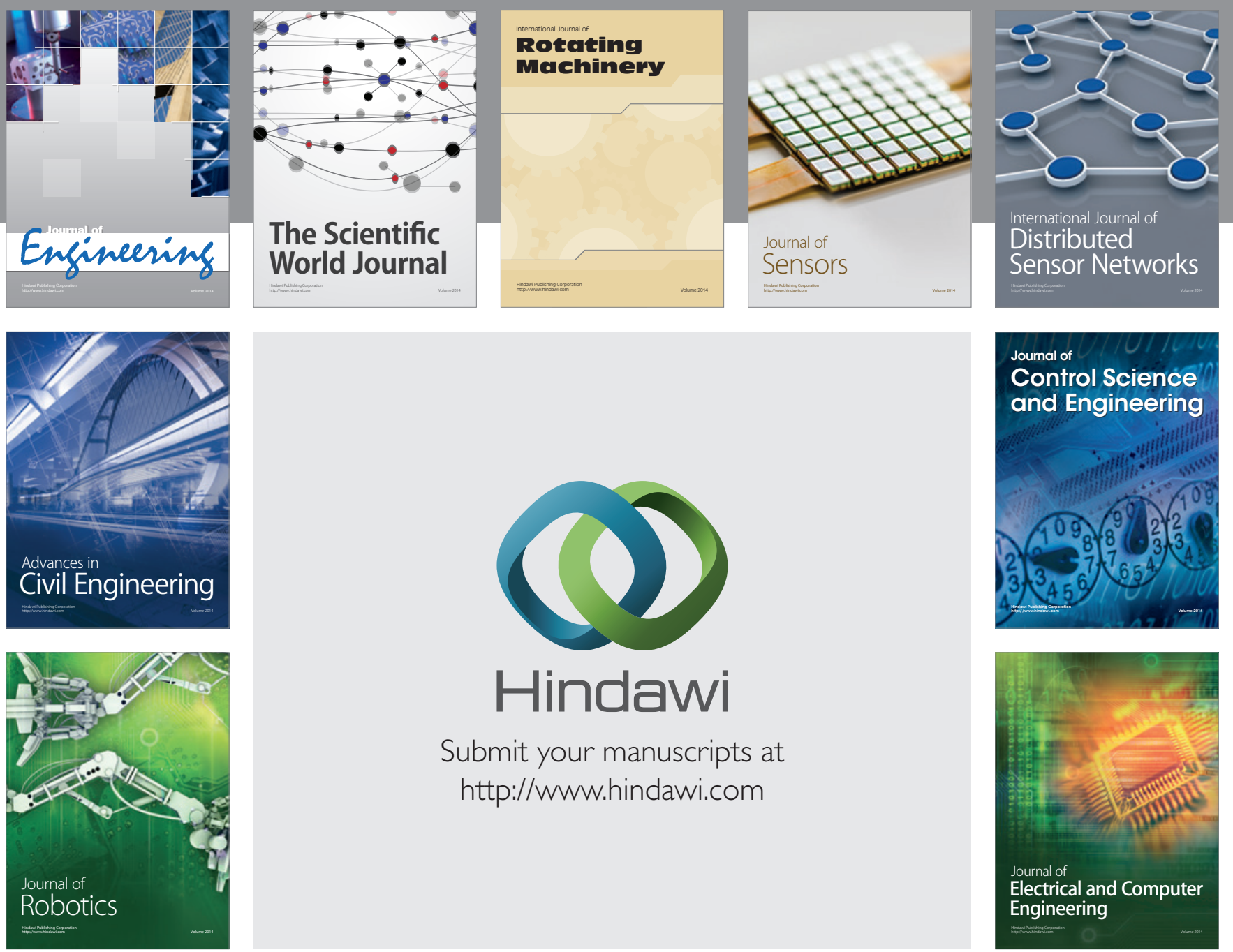

Submit your manuscripts at

http://www.hindawi.com
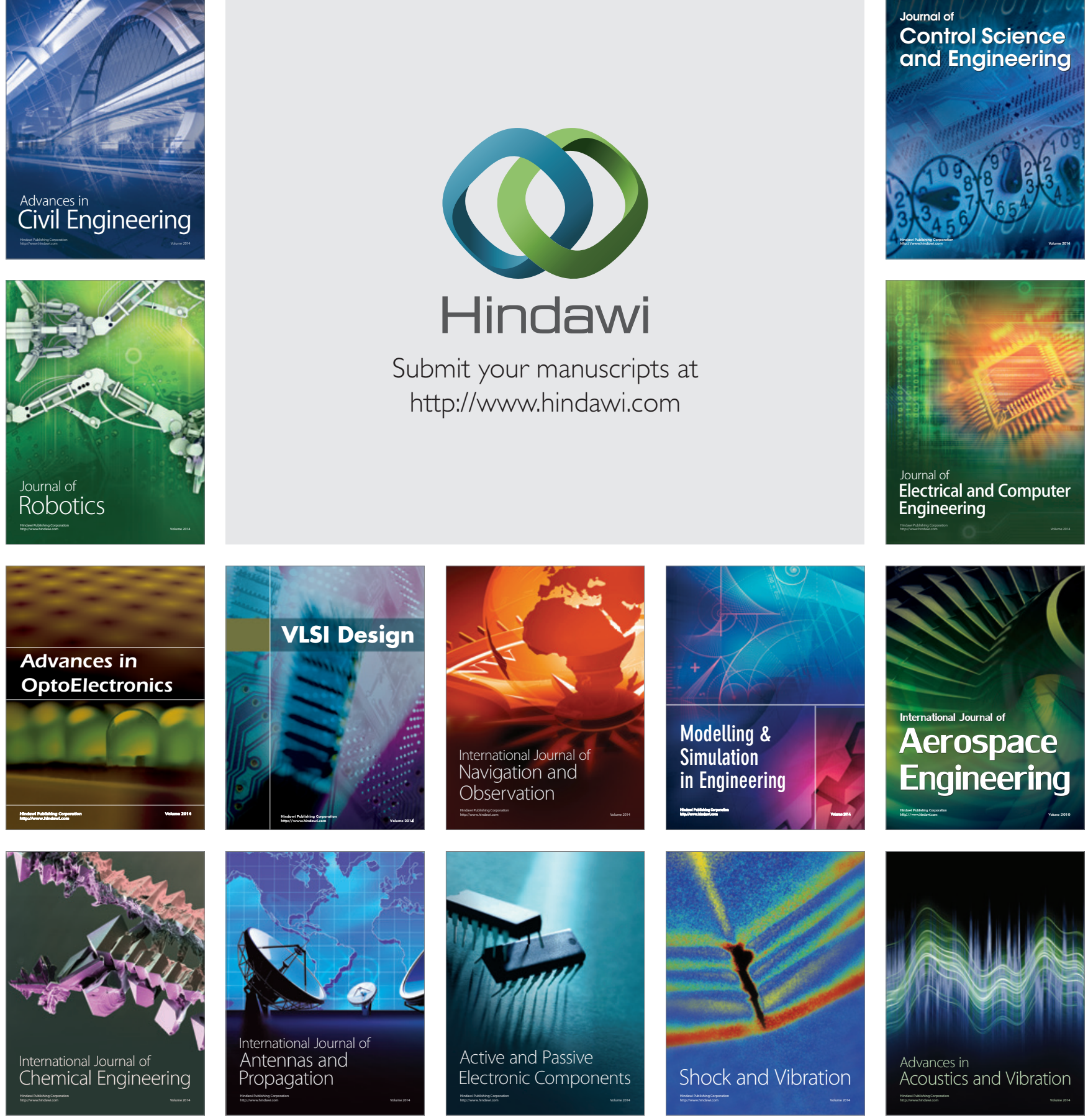